\title{
USE OF THE HYPOSPRAY JET INJECTOR FOR THE INTRA-ARTICULAR AND LOCAL ADMINISTRATION OF HYDROCORTISONE ACETATE*
}

\author{
BY
MORRIS ZIFF†, VINCENT CONTRERAS + , AND FRANK R. SCHMID
From the Department of Medicine and the Study Group on Rheumatic Diseases New York University College of Medicine, New York City

(RECEIVED FOR PUBLICATION JUNE 11, 1956)

The local treatment of rheumatoid arthritis with hydrocortisone acetate was first described by Hollander (Hollander, Brown, Jessar, and Brown, 1951). Improvement was paralleled by reduction of inflammation and by the return of the properties of the synovial fluid towards normal (Ziff, Scull, Ford, McEwen, and Bunim, 1952). It is the purpose of this paper to present the experience of the authors using a hypospray jet injector for the intra-articular and local injection of hydrocortisone acetate, since this instrument offers certain advantages which will be described.

\section{Material and Methods}

The hypospray jet injector T (Figge and Barnett, 1948;

* This work was supported by a grant from the Masonic Foundation for Medical Research and Human Welfare.

+ Senior Fellow, Arthritis and Rheumatism Foundation.

F Rockefeller Foundation Fellow. Present address: Universidad de Chile, Santiago, Chile.

\& Trainee, National Institute of Arthritis and Metabolic Diseases, United States Public Health Service.

T This was obtained from the R. P. Scherer Corp., Detroit, Michigan, through the co-operation of Dr. Alpert, Medical Division, Merck and Co. Inc., Rahway, New Jersey. The hydrocortisone acetate contained in the metapules was provided by Merck and Co. Inc.
Hughes, Jordan, and Hill, 1949) was designed to introduce substances under pressure either subcutaneously or intramuscularly without using a needle (Fig. 1). Its use has been extended to the intra-articular and local injection of hydrocortisone acetate in the present investigation; $1 \mathrm{ml}$. of the material to be injected is contained in metapules, which are small metal cartridges, hermetically sealed in a sterile aluminium container. The mechanism employed to force the medication through the skin is a spring-activated plunger which forces the contents of the metapule through a minute opening in a fine jet. An adjustment sleeve on the instrument permits the injection of $1 \mathrm{ml}$. or an accurate fraction of this amount $(0.6$ to $0.9 \mathrm{ml}$.). No sterilization of the instrument is necessary, because no part of it comes into contact with the sterile materials being injected. Only the skin at the site of injection and the nozzle of the injector need be wiped with alcohol. All injections in the present study were made at maximum spring tension.

Early trials of intra-articular injection were carried out using a standard instrument supplied by the manufacturer, but subsequently a special injector, approximately 18 per cent. more energetic, was made available.

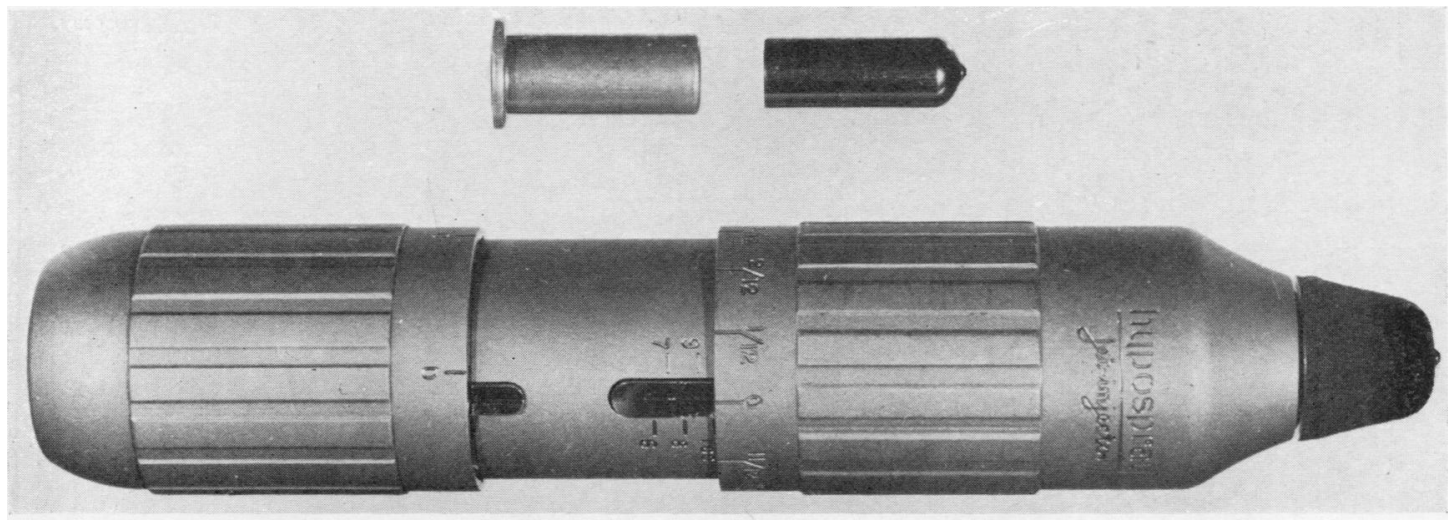

Fig. 1.-Hypospray jet injector, metapule, and cartridge. 
In this report, the terms "standard" and "special" instrument are used to refer to these two models.

\section{Anatomical and Radiological Studies}

Various joints of an unembalmed cadaver were injected by hypospray, using the special instrument and metapules containing trypan blue. The joint was opened within a few minutes after injection at a site opposite to the point of injection. An assessment of the amount of dye in the peri-articular and articular structures and of the degree of penetration of the dye was made (Table I).

TABLE I

INJECTION OF TRYPAN BLUE INTO JOINTS OF A CADAVER

\begin{tabular}{|c|c|c|c|c|}
\hline \multicolumn{2}{|r|}{ Joint } & $\begin{array}{l}\text { Amount } \\
\text { Injected } \\
\text { (ml.) }\end{array}$ & $\begin{array}{c}\text { No. of } \\
\text { Joints } \\
\text { Injected }\end{array}$ & $\begin{array}{l}\text { Dye found } \\
\text { in Synovial } \\
\text { Cavity } \\
\text { (No. of } \\
\text { Joints) }\end{array}$ \\
\hline $\begin{array}{l}\text { Proximal } \\
\text { Metacarp } \\
\text { Wrist } \\
\text { Elbow } \\
\text { Ankle } \\
\text { Shoulder }\end{array}$ & \begin{tabular}{ccc}
\multicolumn{3}{c}{ interphalangeal } \\
ophalangeal & $\ldots$ \\
$\ldots$ & $\ldots$ & $\ldots$ \\
$\ldots$ & $\ldots$ & $\ldots$ \\
$\ldots$ & $\ldots$ & $\ldots$ \\
$\ldots$ & $\ldots$ & $\ldots$
\end{tabular} & $\begin{array}{l}0 \cdot 6 \\
0 \cdot 6 \\
1 \cdot 0 \\
1 \cdot 0 \\
1 \cdot 0 \\
1 \cdot 0\end{array}$ & $\begin{array}{l}5 \\
6 \\
2 \\
2 \\
2 \\
2\end{array}$ & $\begin{array}{l}4 \\
6 \\
2 \\
1 \\
2 \\
2\end{array}$ \\
\hline
\end{tabular}

In all instances the dye was observed to be deposited to some extent in the subcutaneous tissues, especially around the joint capsule.
The synovial cavities of seventeen of nineteen joints injected, however, contained the major portion of the injected dye. When dye was seen in the joint (Fig. 2), it was always present there in greater amounts than in the surrounding tissue.

Diodrast was injected by hypospray into several joints of four patients. These included proximal 듬 interphalangeal (PIP), metacarpophalangeal (MCP), के wrist, and knee joints. $X$-ray films in several planes $\mathbb{\Phi}$ were made within several minutes after injection to determine the course of the dye in the tissues. It was seen that in all these joints a portion of the dye entered the joint cavity and that the remainder was $\overrightarrow{\vec{\omega}}$ deposited peri-articularly. This is demonstrated in $\stackrel{\omega}{\omega}$ a proximal interphalangeal joint in Fig. 3 (opposite).

On the basis of experience with trypan blue and diodrast, the following techniques for hypospray injection were used in the trials reported in this paper. The joint was first palpated to determine $\mathbb{v}$ the location of the joint space. Vessels and tendons 음 were avoided where possible. The PIP, MCP, and metatarsalphalangeal (MTP) joints were injected $\infty$ s either medially or laterally to the extensor tendon. The wrist was injected on the dorsal surface, distally and medially to the styloid process of the ulna in the small depression normally present in this area. The elbow was injected between the head of the radius $\overrightarrow{0}$ and the olecranon process while holding the joing

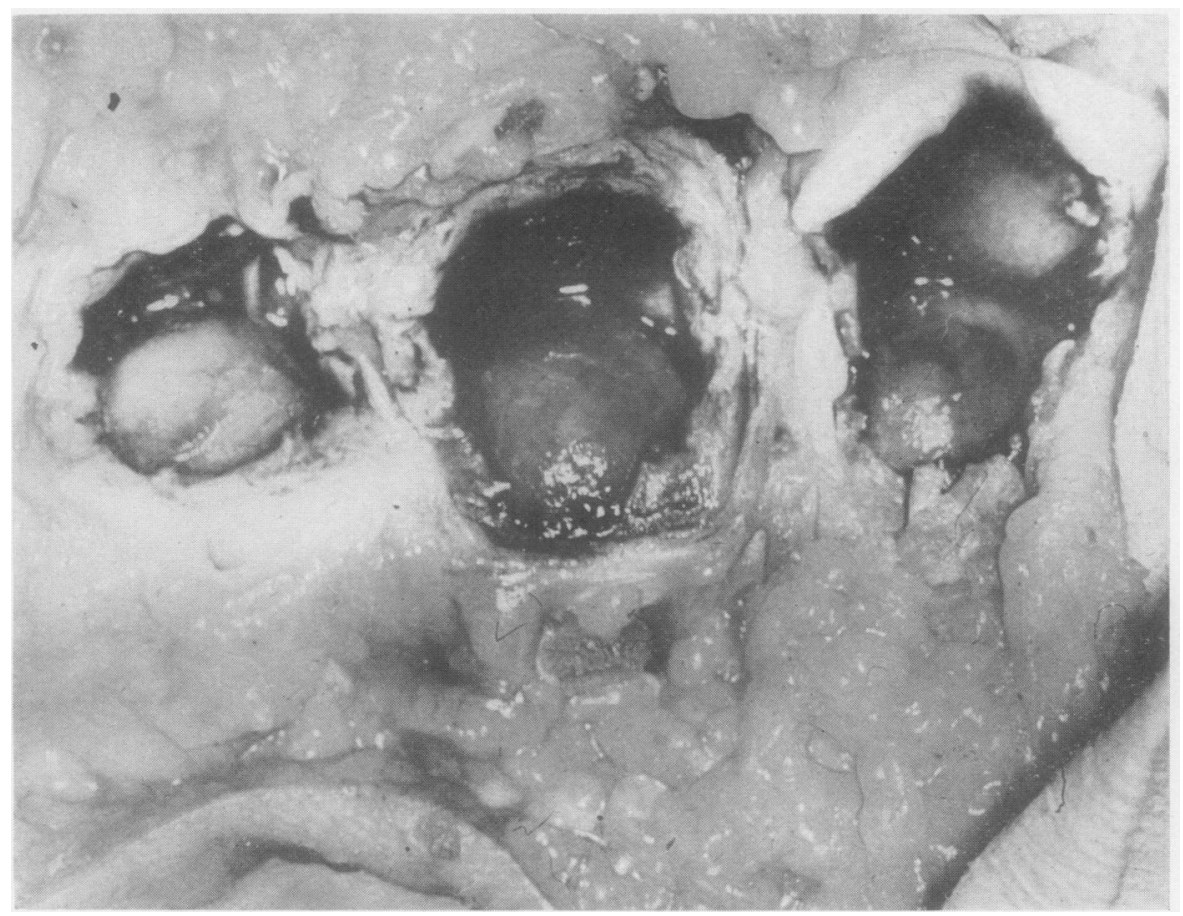

Fig. 2.-Trypan blue in the dissected metacarpo-? phalangeal joint spaces of cadaver after injection by hypospray. 


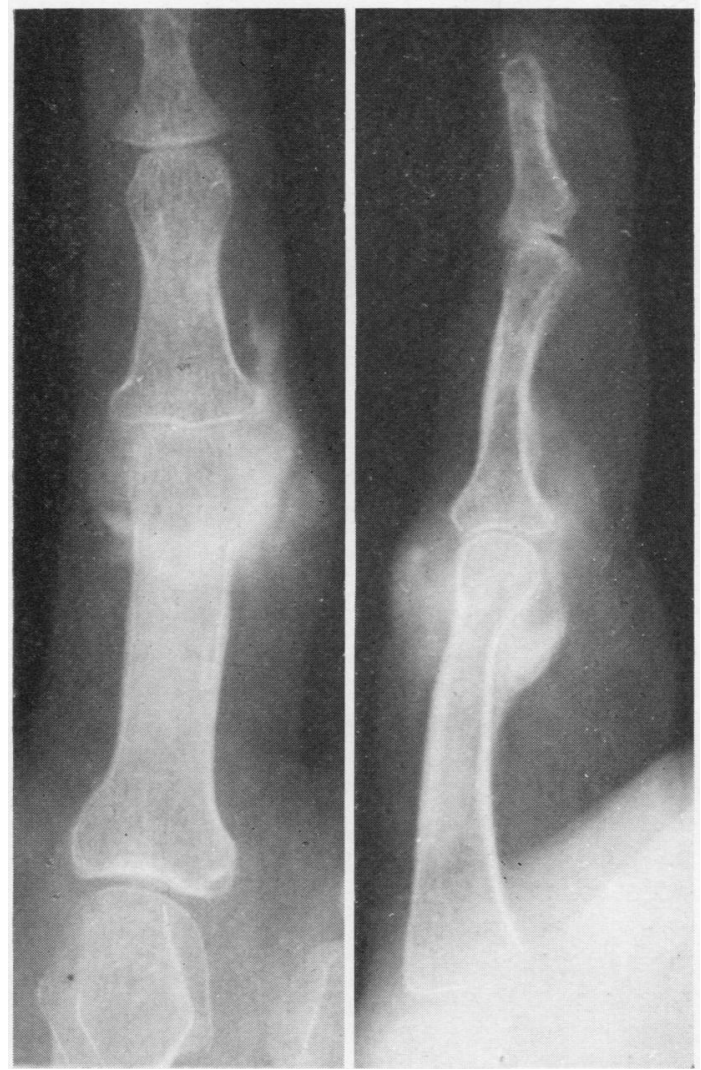

Fig. 3.-Antero-posterior and lateral views of a proximal interphalangeal joint injected with diodrast by hypospray.

in $90^{\circ}$ of flexion. The knee was injected from the medial aspect of the patella, at the mid-patellar level. Manually raising the patella by depressing the lateral edge was of assistance.

In all injections the nozzle of the instrument was held at the injection site with firm and steady pressure to avoid sliding of the instrument and consequent tearing of the skin by the fluid spray. After the injection had been given, the hypospray was held in place for a few seconds to diminish the possibility of subsequent bleeding.

\section{Recovery Studies}

To determine the extent to which the inoculum entered the joint space, experiments on recovery of injected steroid and trypan blue were performed. These were carried out in elbow and knee joints which contained effusions. The joint in each case was first entered by needle and a sample of control fluid was aspirated. The needle was then left in place, and at a point distant from the needle, either hydrocortisone acetate or trypan blue dye was injected by means of the hypospray (special instrument). The joint was then aspirated as completely as possible, either immediately or after a brief period of massage. When $1 \mathrm{ml}$. trypan blue solution was injected (Table II), the aspirated joint fluid was found to contain 59.6 per cent. of the injected dye in the case of the elbow, and 34.5 per cent. in the case of the knee, as determined spectrophotometrically. When $25 \mathrm{mg}$. hydrocortisone acetate were injected into the elbow and knee respectively, assay of the joint fluid obtained by aspiration, using a modified Porter-Silber method (Silber and Porter, 1954), demonstrated 13.6 per cent. of the injected material in the fluid from the elbow and $1 \cdot 2$ per cent. in the fluid from the knee. Presumably most of the remainder of the material was deposited in the synovial membrane and periarticular structures.

TABLE II

RECOVERY OF TRYPAN BLUE AND HYDROCORTISONE ACETATE FROM THE JOINT CAVITY AFTER INJECTION

\begin{tabular}{|c|c|c|c|}
\hline Patient & Joint & Material Injected & $\begin{array}{l}\text { Per cent. } \\
\text { Recovered }\end{array}$ \\
\hline $\begin{array}{c}\text { No. } \\
1 .\end{array}$ & Elbow & \multirow{2}{*}{ Trypan Blue } & $59 \cdot 6$ \\
\hline 2. & Knee & & $34 \cdot 5$ \\
\hline 1. & Elbow & \multirow{2}{*}{ Hydrocortisone Acetate . } & $13 \cdot 6$ \\
\hline 3. & Knee & & $1 \cdot 2$ \\
\hline
\end{tabular}

\section{Clinical Studies}

Clinical studies were carried out mainly in patients with rheumatoid arthritis. These included 33 females and nineteen males, ranging in age from 4 to 65 years.

In addition, the following patients were treated: osteo-arthritis, 3; gout, 1; Reiter's syndrome, 1; non-articular rheumatic conditions, 14.

The small joints were injected with $15 \mathrm{mg}$. hydrocortisone acetate in a volume of $0.6 \mathrm{ml}$, the wrist with $25 \mathrm{mg}$. in $1 \mathrm{ml}$., and the knee with 25 or $50 \mathrm{mg}$. in a 1 or $2 \mathrm{ml}$. volume. The total number of joint injections was 178 .

In cases in which moderate improvement had taken place, a second and, in a few instances, a third and fourth injection were given. Each joint was examined at intervals after injection, usually within 4 days. The examination included an evaluation of pain, tenderness, swelling, effusion, heat, stiffness, and the range of motion in degrees. Swelling of the PIP joints was measured using a conventional set of jeweller's rings. Strength of hand-grip was measured by means of maximum squeeze on a rolled sphygmomanometer cuff inflated initially to $60 \mathrm{~mm}$. 
Hg. Wrist strength was measured on a specially constructed board on which the pressure exerted by the palm pressing a hinged lever against a sphygmomanometer cuff, initially inflated to $60 \mathrm{~mm}$. $\mathrm{Hg}$, was recorded. The result of each injection, or series of injections, was graded 1 to 4 , Grade 1 indicating complete remission, Grade 2 major improvement, Grade 3 minor improvement, and Grade 4 no improvement or worsening.

Table III presents the data obtained on injection of the small joints of the hand, wrist, elbow, and knee, with both the standard and special instruments. It is seen that fourteen of 34 (41 per cent.) and 81 of 123 (66 per cent.) of the joints injected with the standard and special instruments respectively, showed major improvement or better (Grades 1 and 2). With the special instrument, marked improvement was observed in 42 of 49 PIP and MCP joints (86 per cent.), fourteen of 33 wrist joints ( 42 per cent.), and 23 of 39 knee joints (59 per cent.).

TABLE III

GRADE OF IMPROVEMENT OF RHEUMATOID JOINTS AFTER INJECTION WITH HYDROCORTISONE ACETATE

\begin{tabular}{|c|c|c|c|c|c|c|}
\hline \multirow[b]{2}{*}{ Instrument } & \multirow{2}{*}{$\begin{array}{c}\text { Grade } \\
\text { of } \\
\text { Improve- } \\
\text { ment }\end{array}$} & \multicolumn{4}{|c|}{ No. of Joints } & \multirow{2}{*}{ Total } \\
\hline & & $\begin{array}{l}\text { PIP } \\
\text { and } \\
\text { MCP }\end{array}$ & Wrist & Knee & Elbow & \\
\hline \multirow{5}{*}{ Standard } & 1 & 1 & 0 & 0 & 0 & 1 \\
\hline & 2 & 5 & 8 & 0 & 0 & 13 \\
\hline & 3 & 2 & 6 & 0 & 4 & 12 \\
\hline & 4 & 1 & 7 & 0 & 0 & 8 \\
\hline & Total & 9 & 21 & 0 & 4 & 34 \\
\hline \multirow{5}{*}{ Special } & 1 & 17 & 3 & 3 & 1 & 24 \\
\hline & 2 & 25 & 11 & 20 & 1 & 57 \\
\hline & 3 & 6 & 16 & 13 & 0 & 35 \\
\hline & 4 & 1 & 3 & 3 & 0 & 7 \\
\hline & Total & 49 & 33 & 39 & 2 & 123 \\
\hline
\end{tabular}

In fourteen patients, nineteen joints (PIP, MCP and wrist) were injected repeatedly, on the average three times, at 3- to 7-day intervals. In seven of these joints, repeated injections produced further im provement over that following the initial injection $\frac{\vec{P}}{4}$

As a control for the injection of hydrocortisoneo single injections of saline were given into PIP and wrist joints, and in one case into the elbow joint $\frac{\bar{s}}{2}$ simultaneously with injection of hydrocortison acetate into homologous or contralateral joints of similar states of inflammation. The patients were unaware of the substitution. Using the standarP injector, six of twelve joints showed major improve $\vec{\omega}$ ment or better when injected with hydrocortisone acetate, while only one of twelve showed similap improvement when injected with saline. Using the special instrument, eight of twelve joints showedr major improvement when injected with hydro cortisone, while none showed similar improvement after saline injection, although three of the patients described subjective improvement.

Table IV shows a comparison of measurementss after the injection of hydrocortisone acetate an $\mathbb{B}$ saline respectively into contralateral wrist joints $\overrightarrow{\mathbb{Q}}$ the same patient. It is seen that though the hydro cortisone-injected wrist improved markedly, the wrist which was injected with saline showed improvement.

In three patients with osteo-arthritis and sy商vitis, involving in one instance the knee and in twㅜㅇ the PIP joints, in one patient with gouty arthritis of knee, and in one with Reiter's syndrome involving the wrist, hypospray injection was followed by majo improvement in each case.

Our experience with the treatment of non $\overrightarrow{\overrightarrow{0}}$ articular rheumatism has been brief. Injections were usually made at the site of maximum tender ness. Four of six patients with acute subdeltoid. bursitis were strikingly improved within 24 hours after two injections of $25 \mathrm{mg}$. hydrocortisone acetate given one immediately after the other. One patient

TABLE IV

COMPARISON OF EFFECTS OF INJECTION OF HYDROCORTISONE ACETATE AND SALINE INTO WRISTS (MALE, AGED 55, RHEUMATOID ARTHRITIS)

\begin{tabular}{|c|c|c|c|c|c|c|c|c|c|c|c|}
\hline Wrist & Injec & & & $\begin{array}{l}\text { Circum- } \\
\text { ference } \\
\text { (inches) }\end{array}$ & $\begin{array}{c}\text { Tender- } \\
\text { ness }\end{array}$ & Effusion & $\begin{array}{l}\text { Pain on } \\
\text { Motion }\end{array}$ & Flexion & Extension & $\underset{(\mathrm{mm} .}{\text { Grip }}$ & $\begin{array}{l}\text { Wrist } \\
\text { Pressure } \\
\text { (mm. Hg) }\end{array}$ \\
\hline \multirow{2}{*}{ Right } & \multirow{2}{*}{ Hydrocortisone } & Before & $\cdots$ & $9 \cdot 2$ & $3+$ & $4+$ & $2+$ & $20^{\circ}$ & $40^{\circ}$ & 125 & 110 \\
\hline & & After* & $\cdots$ & $8 \cdot 0$ & \pm & $2+$ & $1+$ & $45^{\circ}$ & $45^{\circ}$ & 150 & 140 \\
\hline \multirow{2}{*}{ Left } & \multirow{2}{*}{ Saline } & Before & $\cdots$ & $8 \cdot 5$ & $3+$ & $3+$ & $2+$ & $45^{\circ}$ & $45^{\circ}$ & 130 & 110 \\
\hline & & After* & . & $8 \cdot 5$ & $3+$ & $3+$ & $2+$ & $30^{\circ}$ & $45^{\circ}$ & 130 & 140 \\
\hline
\end{tabular}


with non-specific tenosynovitis of the extensor tendons of the foot, and five with rheumatoid tenosynovitis of a flexor tendon of the hand obtained prompt relief of pain within 24 hours. Three of the latter group, who had flexion contractures of approximately 10 to $30^{\circ}$ at the MCP joint, were completely relieved within 3 days with restoration of full extension. One patient with De Quervain's syndrome showed marked improvement within the same period of time.

\section{Undesirable Effects}

No serious undesirable effects have resulted from the hypospray injections. Some relatively minor complications should, however, be pointed out. Practically all of the patients who received injections over the joint had some degree of discomfort at the moment of injection. This was described as a sudden, sharp, or burning sensation. The first injection was generally more uncomfortable than succeeding ones, since, presumably much of the discomfort was due to the element of surprise. In about one-third of the patients, the post-injection pain was severe enough to cause the subject to complain for periods up to a few minutes after the injection. Injection of the PIP and MCP joints was less well tolerated than injection of the large joints. This was very likely related in part to the sudden distension of a relatively small intra-articular and peri-articular space by the fluid injected, and in part to trauma to the periosteum created by the jet. In no case was pain a reason for discontinuing treatment when subsequent improvement occurred.

The authors have on a number of occasions injected their own normal joints and confirmed these observations. The discomfort at the moment of injection proved relatively slight; mild pain on motion and stiffness persisted for about 24 hours.

Six instances of minor ecchymosis at the site of injection were recorded. In one patient who was injected in the wrist, there developed an area of numbness about $1 \mathrm{~cm}$. in diameter on the dorsum of the hand, which has continued to be present for 7 months. In another, injection on the lateral aspect of the knee was followed by bleeding from a small subcutaneous artery which was halted within a minute or two by application of a pressure bandage. In no instance did infection or worsening of the joint follow the injection of hydrocortisone.

\section{Discussion}

On the basis of direct observation of injected material in the joint and recovery from the joint fluid, and on the basis of clinical evaluation, it appears that penetration of the joint by hypospray injection did occur. It is also apparent that not all of the injected material entered the joint cavity. $X$-ray evidence indicated that that portion of the material which did not enter the joint was deposited in and about the peri-articular tissues in close proximity to the joint. While it is likely that penetration of the articular space is essential for a good therapeutic result, it seems probable that material deposited diffusely in and around the inflamed synovial membrane and joint capsule would also exert a beneficial effect. In the treatment of non-articular rheumatism, such as periarthritis and tenosynovitis, the value of the local infiltration of hydrocortisone is well recognized. Since the inflammation in rheumatoid arthritis is often peri-articular, the tendency of the hypospray jet to spread in the peri-articular tissue may be advantageous. Certainly, the results of the clinical trials recorded in this report are encouraging and compare favourably with those reported by needle injection (Hollander, Brown, and Jessar, 1954).

A practical feature of the hypospray injection is the simplicity of the technique. The physician can inject several joints in a short time without the preliminary preparation required for needle injection. In the experience of the authors, most of the patients who had had previous injections by needle preferred the hypospray.

Indications for use of the hypospray appear to be the same as for intra-articular injection by needle. The joint to be injected should be actively inflamed. Where irreversible damage is a major cause of disability little improvement may be expected, nor is the procedure warranted in the presence of generalized joint involvement. It must also be pointed out that the hypospray procedure has the disadvantage that it does not permit the withdrawal of fluid for diagnostic or therapeutic purposes. For injection of the hip, which it is not possible to penetrate by hypospray, the needle injection procedure remains the only one available. We have had no experience with injection of the shoulder joint.

Most of the results reported here refer to patients with rheumatoid arthritis, but the method has proved useful in other conditions known to be benefited by local hydrocortisone injection. The data obtained indicate that injection of the smaller joints results in a higher incidence of improvement than in the case of larger joints such as the wrist and the knee. This is probably due to the fact that the peri-articular structures of the smaller joints are more easily penetrated.

\section{Summary}

The hypospray jet injector has been applied to intra-articular injection. On the basis of recovery 
of injected trypan blue and hydrocortisone acetate in the synovial fluid, it appeared that a significant portion of injected material penetrated the joint cavity. Radiological studies after the injection of diodrast demonstrated the dye both intraarticularly and peri-articularly.

Injections were made with both a standard instrument and a more energetic jet injector. With the latter, 66 per cent. of 123 injections of various joints of patients with rheumatoid arthritis showed major improvement. A small group of patients with other types of arthritis and with non-articular rheumatism were also treated with good results. The small joints of the hands obtained the most benefit.

The hypospray injection technique is simple and the procedure convenient. No serious complications have resulted.

\section{REFERENCES}

Figge, F. H. J., and Barnett, D. J. (1948). Amer. Pract., 3, 197. Hollander, J. L., Brown, E. M., Jr., and Jessar, R. A. (1954), Med.

$-\frac{\text { Clin. N. Amer., 38, 349. }}{1629}$.

Hughes, J. G., Jordan, R. G., and Hill, F. S. (1949). Sth. med. J., 42, 296.

Silber, R. H., and Porter, C. C. (1954). J. biol. Chem., 210, 923.

Ziff, M., Scull, E., Ford, D., McEwen, C., and Bunim, J. J. (1952). A. M. A. Arch. intern. Med., 90, 774 .

Emploi de l'injecteur à jet "Hypospray" pour l'administration intra-articulaire et locale d'acétate d'hydrocortisone

RÉSUMÉ

L'injecteur à jet "Hypospray" a été utilisé pour l'injection intra-articulaire. Sur la base de la récupéra- tion dans le liquide synovial du trypan bleu et de l'acétate d'hydrocortisone injectés, il apparut qu'une substantielle quantité du produit pénétrait la cavité articulaire. DesD études radiologiques après l'injection de "Diodrast'? révélèrent sa présence dans et autour de l'articulation.

Des injections furent faites à la fois avec un instruments standard et avec un injecteur à jet plus énergique. Ave ce dernier, $66 \%$ de 123 injections dans diverses articulae tions de malades atteints d'arthrite rhumatismale montrèrent une importante amélioration. Un petiff groupe de malades atteint d'autres types d'arthrite et do rhumatisme non articulaire fut aussi traité avec de bonş résultats. Les petites articulations des mains obtinren le plus de bénéfice.

La technique de l'injection à l'“Hypospray" est simple et le procédé commode. Aucune complication sérieuse n'en a résulté.

Empleo del eyector "Hypospray" para la administracióñ intra-articular y local de acetato de hidrocortisona $O$ Sumario

El eyector "Hypospray" fué empleado para inyeod ciones intra-articulares. La recogida del líquido sinovia de tripan azul y de acetato de hidrocortisona inyectados permite estimar que una cantidad substancial det producto penetra la cavidad articular. Estudios radioss lógicos después de la inyección de "Diodrast" revelaro la presencia de éste dentro y alrededor de la articulaciór Se hicieron inyecciones con un instrumento ordinari $\bar{Q}$ y con un eyector más fuerte. Con el último, el $66 \%$ d 123 inyecciones en diferentes articulaciones de enfermos con artritis reumatoide reveló una mejoría importą̧tę Se obtuvieron también buenos resultados en un pequẹ̃no grupo de enfermos afectos de otros tipos de artritis $y$ de reumatismo extra-articular. Las pequeñas articulaci\&ges de las manos beneficiaron más.

$\mathrm{La}$ inyección con "Hypospray" es técnicamento sencilla y el procedimiento es cómodo. No hub complicaciones de importancia. 